\title{
Measurement of epithelial thickness within the oral cavity using optical coherence tomography (OCT)
}

\author{
Sven Prestin ${ }^{1 *}$, Christian Betz $^{2}$, Marcel Kraft ${ }^{1}$ \\ From 2nd Scientific Meeting of the Head and Neck Optical Diagnostics Society \\ San Francisco, CA, USA. 23-24 January 2010
}

Optical coherence tomography (OCT) is a promising method in the early diagnosis of oral cavity cancer. The objective of the present study is to determine normal values of epithelial thickness in the oral cavity, as no such data are to be found in the literature. In healthy test persons, epithelial thickness of the oral mucosa was determined with the help of OCT separately for each side at nine different locations. Special attention was directed to those sites having the highest incidence for the development of dysplasias and carcinomas. Depending on the location within the oral cavity, the epithelium demonstrated a varying thickness. The highest values were found in the region of the tongue and the cheek, whereas the floor of the mouth showed the thinnest epithelium. Our data serve as reference values for detecting oral malignancy and determining the approximate grade of dysplasia. In this circumstance, a differentiated view of the different regions is important due to the variation in thickness of the epithelium within the normal oral cavity.

\section{Author details}

'Department of Otorhinolaryngology, Head and Neck Surgery, Kantonsspital AG, Aarau, Switzerland. '2Department of Otorhinolaryngology, Head and Neck Surgery, Ludwig Maximilian University, Munich, Germany.

Published: 29 October 2010

doi:10.1186/1758-3284-2-S1-042

Cite this article as: Prestin et al:: Measurement of epithelial thickness within the oral cavity using optical coherence tomography (OCT) . Head \& Neck Oncology 2010 2(Suppl 1):042.

'Department of Otorhinolaryngology, Head and Neck Surgery, Kantonsspital AG, Aarau, Switzerland

Full list of author information is available at the end of the article
Submit your next manuscript to BioMed Central and take full advantage of:

- Convenient online submission

- Thorough peer review

- No space constraints or color figure charges

- Immediate publication on acceptance

- Inclusion in PubMed, CAS, Scopus and Google Scholar

- Research which is freely available for redistribution

Submit your manuscript at www.biomedcentral.com/submit
C Biomed Central 